\title{
Blue growth and ocean governance- - how to balance the use and the protection of the seas
}

\author{
Peter Ehlers ${ }^{1}$
}

Received: 25 June 2015 / Accepted: 19 April 2016 / Published online: 11 May 2016

(C) World Maritime University 2016

\begin{abstract}
The economic value of the oceans and maritime industry is strongly gaining in importance. As the oceans are very large and particularly sensitive ecosystems, which need to be preserved, a balance between the use and the protection of the seas has to be found. On this issue, the paper presents some thoughts starting with a brief analysis of what to understand by maritime industry which is labeled as blue economy, and a recapitulation of the main threats for the marine environment, caused by blue economy. After that, some noteworthy prerequisites and criteria for finding a sound balance between the use and the protection of the seas will be highlighted, especially the need for sustainable ocean governance is put to discussion.
\end{abstract}

Keywords Blue growth - Maritime industry - Ocean governance - Marine environment Sustainable development $\cdot$ Law of the sea

\section{Introduction}

What are our feelings when we reach the sea shore: a limitless expanse of water, you can see as far as the horizon, and somehow beyond it. The ocean seems to be the last frontier, as John Milton felt more than 300 years ago when he wrote "Paradise Lost":

"A dark

Illimitable ocean without bound,

Without dimension, where length, breadth, and highth

And time and place are lost."(Milton 1674)

Peter Ehlers

peter.ehlers@gmx.de

1 Federal Maritime and Hydrographic Agency of Germany (ret.), Institute for Law of the Sea and Maritime Law, Hamburg University, Hamburg, Germany 
Is that still true today? Haven't the oceans turned into an intensively used economic area which is becoming more congested from day to day? That applies in particular to coastal waters and thus to the European seas in general which today are anything but a vast and pristine expanse of water. ${ }^{1}$ In addition to their territories coastal states exercise their powers more and more also in their "aquitories" ${ }^{2}$ which cover the territorial sea and marine internal waters. But, states are increasingly extending their rights and jurisdiction by establishing EEZs ${ }^{3}$ in compliance with international law ${ }^{4}$ which leads to an "aquitorialization" of the EEZ. ${ }^{5}$ However, the activities for economic exploitation and exploration of the seas, labeled as blue economy ${ }^{6}$, go far beyond the EEZs and the continental shelf areas of coastal states. ${ }^{7}$

Since some years, the economic value of the oceans and maritime industry is strongly gaining in attention. On the European level — and these considerations are mainly concentrated on Europe - one of the outcomes was a new holistic approach which led to the European integrated maritime policy. ${ }^{8}$ This integrated policy must not only focus on maritime industry and social interests but at the same time has to care for the protection of the marine environment. The oceans are very large and particularly sensitive ecosystems, which need to be preserved. So, a balance between the use and the protection of the seas has to be found. On this issue, the paper presents some thoughts starting with a brief analysis of what to understand by maritime industry which is labeled as blue economy. That will be followed by summing up the main threats for the marine environment, caused by blue economy. After that some noteworthy prerequisites and criteria for finding a sound balance between the use and the protection of the seas will be highlighted, especially the need for sustainable ocean governance is put to discussion.

\section{The significance of the blue economy}

Nowadays, maritime industry is recognized as a significant part of economy. And as everyone is striving for economic growth, a new magic word has been created: blue growth. ${ }^{9}$ Indeed, the seas and oceans have the potential to be a major source of new jobs and growth. According to the European Commission, the EU's blue economy represents 5.4 million jobs and a gross value added of just under $€ 500$ billion per year. $^{10}$

\footnotetext{
${ }^{1}$ Cf. House of Lords, The North Sea under Pressure: is regional marine co-operation the answer?, 10th Report of the Session 2014-2015, HL Paper 137, 2015, p. 4.

${ }^{2}$ See (Vitzthum 2006).

${ }^{3}$ Exclusive economic zone.

${ }^{4}$ Art. 55 et seq. United Nations Convention on the Law of the Sea (UNCLOS)

${ }^{5}$ See in detail Peter Ehlers, Meeresfreiheit und aquitoriale Ordnung. Zur Entwicklung des Seerechts, VwArch 2013, vol. 3, p.406, 415 et seq.

6 This term was first used by Gunter Pauli, The Blue Economy-10 years, 100 innovations, 100 million jobs, 2010 .

${ }^{7}$ As concerns the rights of states over the continental shelf see Art. 77 et seq. UNCLOS.

${ }^{8}$ See European Commission, COM(2007) 575 final; COM(2012) 491 final.

${ }^{9}$ See European Commission, COM(2012) 494 final.

${ }^{10}$ Ibid., p. 2.
} 


\subsection{Traditional maritime industry}

But, what to understand by blue economy? First of all that covers what may be called the traditional maritime industry: maritime transportation as the core of maritime industry, including port services and shipbuilding, as well as fisheries, and also the exploitation of oil and gas from the seas. These sectors are still gaining in importance.

\subsubsection{From time immemorial, the oceans have been transport routes of vital importance}

It is impossible to imagine a world economy without maritime transportation as the driving belt for a globalized commerce. More than $95 \%$ of the intercontinental trade of goods and $40 \%$ of trade within the European Union rely on maritime transportation. About 55,000 commercial vessels ply the oceans, with a transport volume of 10 billion tons ${ }^{11}$.

\subsubsection{At the heart of maritime uses are fisheries, which have been pursued on an industrial scale worldwide for a long time now}

Fish is indispensable to provide food high in protein. Eighty million tons of fish are captured annually in marine fishing areas. ${ }^{12}$

2.1.3 An important sector is the exploitation of oil and gas from the sea which has been practiced since decades; therefore, it is already a traditional part of maritime industry

Today, North Sea production, for example, still covers a considerable part of Europe's energy demand.

\subsection{New economic areas}

However, traditional maritime industry is more and more supplemented by new economic areas. The European Commission has identified five sectors with a high potential for growth ${ }^{13}$ :

- Aquaculture

- Coastal and maritime tourism (blue tourism)

- Marine biotechnology (blue biotechnology)

- Ocean energy (blue energy)

- $\quad$-Seabed mining

\footnotetext{
${ }^{11}$ Verband Deutscher Reeder, Daten der deutschen Seeschifffahrt, Ausgabe 2014, p. 5, 18.

${ }^{12}$ Food and Agricultural Organization, The State of World Fisheries and Aquaculture 2012, p. 3, table 1, p. 11.

${ }^{13}$ European Commission (fn 9), p. 6 et seq.
} 
2.2.1 Aquaculture, a close relative of fisheries, is the world's fastest growing sector in the food producing industry, covering not only the production of fish and shellfish but also aquatic plants. ${ }^{14}$

Global production has been growing annually at 7 to $8 \%{ }^{15}$ Although most of the aquaculture production which already provides nearly half of the global consumption of fish and shellfish ${ }^{16}$ comes from pond culture, the marine sector has been gaining in importance. More than 600 species are raised worldwide by aquaculture. ${ }^{17}$ The cultivation of algae is practiced in about 30 countries with a total production of approximately 19 million tons per year and a growth rate similar to that of fish and shellfish. ${ }^{18}$ In Europe, aquaculture accounts for $20 \%$ of fish production, amounting to about 1.26 million tons annually with a value of $€ 3.1$ billion $^{19}$ and providing around 80,000 jobs. Having the potential to grow aquaculture may help coastal communities to diversify and alleviate fishing pressure. ${ }^{20}$

\subsubsection{Coastal and maritime tourism though often overlooked, when speaking about maritime industry, is the largest single maritime economic activity in Europe}

In particular, open water activities, namely yachting as well as the cruise industry, are steadily increasing. The blue tourism sector employs over 3.2 million of people and generates a total of $€ 183$ billion in gross value added per year representing one third of the maritime economy (ECORYS 2013).

2.2.3 Compared to tourism, blue biotechnology still is a small niche market for Europe with a gross value added of less than $€ 1$ billion though some remarkable success stories may already be noted. ${ }^{21}$

In 2010 , the global market was estimated at $€ 2.8$ billion with an annual growth rate of at least 4-5\%. Less conservative predictions of an annual growth of up to $12 \%$ reveal the high expectations for further developments (European Science 2010) as marine organisms attract more and more attention in order to develop new products, in particular not only for pharmaceuticals and cosmetics but also for food, feed, and the chemical industry. Research has focused on marine microorganisms as a nearly inexhaustible source of novel biological agents, also including the production of bio-energy. 22 The deep sea, in particular hydrothermal vents, the so-called black smokers, and

\footnotetext{
${ }^{14}$ For a detailed description of aquaculture see German Advisory Council on Global Change (WBGU), World in Transition - Governing the Marine Heritage, Flagship Report, 2013, p. 153 et seq, available under http:// www.wbgu.de/en/flagship-reports/fr-2013-oceans (last visit 24 March 2015).

${ }^{15}$ See the different estimates by the European Commission, http://ec.europa.eu/fisheries/cfp/aquaculture/ index en.htm (last visit 22 January 2014) and World Ocean Review 2 (WOR 2), 2013, p. 80, available under http://worldoceanreview.com/wp-content/downloads/wor2/WOR2_english.pdf (last visit 20 May 2015).

16 Ibid.

${ }^{17}$ Ibid., p. 82 .

${ }^{18}$ Ibid., p. 83; for the use of algae as an energetic resource see WBGU (fn 14), p. 212.

${ }^{19}$ European Commission, $\operatorname{COM}(213) 229$ final, p. 2.

${ }^{20}$ European Commission (fn 9), p. 8.

${ }^{21}$ Cf. European Commission (fn 9), p. 11.

22 Ibid., p. 37 et seq.
} 
polar regions have become areas of special interest. Approximately 10,000 natural substances are said to have been discovered worldwide by now. ${ }^{23}$ However, this figure appears much less impressive when one considers the fact that an estimated $80 \%$ of all living organisms inhabit aquatic environments. ${ }^{24}$ Subject to further technological breakthroughs, blue biotechnology will become an emerging market offering great potentials of marine aquatic products.

\subsubsection{Marine renewable energy including both offshore wind power and ocean energy} will increasingly contribute to meet our energy demands ${ }^{25}$ and to reduce greenhouse emissions

Experts estimate that offshore wind power could in future supply $5000 \mathrm{TWh}^{26}$ of electricity worldwide per year. ${ }^{27}$ Offshore wind farms are rapidly expanding. ${ }^{28}$ The total installed capacity in Europe is projected to produce approximately $14 \%$ of the EU's total electricity consumption by $2030 .{ }^{29}$ However, wind energy is only a partial aspect.

An even more interesting aspect is the technological challenge of exploiting the almost unlimited energy resources of the oceans by making use of tidal streams, waves, and currents as well as of differences in temperature or salinity. ${ }^{30}$ Although the technological developments are still at an early stage and require a lot of technological improvement and innovation, the first plants have been put into operation. Various tidal power stations exist already all over the world, especially in China, Russia, South Korea, and North America, not to forget the very first modern station which is already old fashion, close to St. Malo in France. ${ }^{31}$ The global potential of wave energy is estimated at 11,400 TWh per year. ${ }^{32}$ Off the Orkney Islands, for example, a wave energy plant has been put into operation. ${ }^{33}$ A thermal energy conversion plant exists off Hawaii. ${ }^{34}$ In the Strait of Messina, a current energy plant is planned to be built. ${ }^{35}$ The first prototype of an osmotic power plant, making use of the salt difference between seawater and river water, was developed in Norway by Statkraft; however, the work was discontinued in 2013, as the costs cannot compete with other technologies. ${ }^{36}$

\footnotetext{
${ }^{23}$ See in detail World Ocean Review 1 (WOR 1), 2010, p. 178 et seq; available under http:// worldoceanreview.com/wp-content/downloads/wor1/WOR1 english.pdf (last visit 20 May 2015); the European Science Foundation, p. 17, refers to over 18.000 natural products and 4.900 patents associated with genes of marine organisms.

${ }^{24}$ Cf. marinebio.org/marinebio/facts/ (last visit 8 February 2015).

${ }^{25}$ For the potentials of ocean energy see WBGU (fn. 14), p. 212 et seq.

26 Terawatt-hours.

${ }^{27}$ WOR 1, (fn 23), p. 156.

${ }^{28}$ For details see WBGU (fn. 14), p. 205 et seq.

${ }^{29}$ European Commission (fn 9), p. 7.

${ }^{30}$ WOR 1 (fn 23); p.156.

${ }^{31} \mathrm{Cf}$. http://www.power-technology.com/features/featuretidal-giants - the-worlds-five-biggest-tidal-powerplants-4211218/ (last visit 8 February 2015); WBGU (fn. 15), p. 209 et seq.

${ }^{32}$ WOR 1 (fn 23), p. 157; WBGU (fn. 15), p. 208 et seq.

${ }^{33}$ For details see http://www.emec.org.uk/about-us/emec-history/ (last visit 8 February 2015).

34 See Vega, Ocean Thermal Energy Conversion, Encyclopedia of Sustainability Science and Technology, p. 7296 et seq.

${ }^{35}$ See El-Geziry and others, Environmental impact assessment for tidal energy schemes: an exemplar case study of the Strait of Messina, Journal of Marine Engineering \& Technology, 8:1, p. 39 et seq.

${ }^{36} \mathrm{http} / /$ www.statkraft.com/media/news/News-archive/2013/Statkraft-halts-osmotic-power-investments/ 20. 12.1213 (last visit 9 February 2015).
} 


\subsubsection{In the past, seabed mining concentrated on the offshore exploitation of oil and gas}

This industry is still growing, as the consumption of fossil fuels will further increase. It is estimated that one quarter of the oil reserves are to be found in offshore areas. Offshore gas production currently counts for one third of the worldwide production. ${ }^{37}$ Extraction activities are expanding to depths of $2000 \mathrm{~m}$ and more and to remote areas with fragile ecosystems, including regions covered by ice. ${ }^{38}$ Scientific studies suggest that $30 \%$ of undiscovered gas and $13 \%$ of undiscovered oil can be found in the Arctic Region. ${ }^{39}$

As concerns mineral resources, sand and gravel have been extracted from shallow coastal seas already for a long time. ${ }^{40}$ Current mining activities also include diamonds off the coast of South Africa and tin, titanium, and gold along the shores of Africa, Asia, and South America. ${ }^{41}$ The increasing request for raw materials ${ }^{42}$ encourages new commercial activities to exploit mineral resources from the deep-sea floor, targeting polymetallic nodules and sulfides, cobalt-rich crusts, and rare earth element-rich deep sea sediments. Polymetallic nodules which cover huge areas below $4000 \mathrm{~m}$ are mainly not only composed of manganese and iron but also include cobalt, copper, and nickel in lower concentrations as well as traces of rare earth elements. Massive sulfides occur at submarine plate boundaries, especially forming "black smokers." Cobalt crusts are found in water depths of 1000 to $3000 \mathrm{~m}$ on the flanks of submarine volcanoes; they contain manganese and iron, cobalt, copper nickel, and platinum. ${ }^{43}$ Various exploration projects are on their way, partly within the EEZ area, partly on the high seas, the socalled Area, ${ }^{44}$ where an authorization of the International Seabed Authority is required. ${ }^{45}$ It is expected that in the coming years, first exploitation activities will start. Quite optimistically, the European Commission estimates that by $2020,5 \%$ of the world's minerals, including cobalt, copper, and zinc, could come from the ocean floors; this could rise to $10 \%$ by 2030 . Accordingly, the annual turnover of marine mineral mining may grow from virtually nothing to $€ 10$ billion by $2030 .{ }^{46}$ But, prior to that, major technological challenges need to be overcome.

What the European Commission has not included in its considerations are gas hydrates which are an ice-like solid mixture combined of water and methane gas. They are widespread in marine sediments primarily on the continental margins. Recent estimates of the worldwide amount of gas hydrates vary between 500 and $1500 \mathrm{Gt}$ of carbon, whereas the conventional reserves of natural gas are estimated at $100 \mathrm{Gt}^{47}$ Some consider it to be the most important resource of fossil energy of the future, substituting oil and gas in the longer run, provided that the risks inherent in its

\footnotetext{
${ }^{37}$ WOR 1 (fn 23), p. 142 et seq.

${ }^{38}$ For details see World Ocean Review 3 (WOR 3), 2014, p. 17 et seq., available under

${ }^{39}$ WOR 1 (fn 23), p. 145; WOR 3 (fn 41), p. 19; for details see WBGU (fn. 15), p. 194.

${ }^{40}$ Cf. WBGU (fn. 14), p. 37.

41 Ibid.

42 European Commission (fn 9), p. 10.

${ }^{43}$ For details see WOR 1 (fn 23), p. 146 et seq.; WBGU (fn. 14), p. 51 et seq.

${ }^{44}$ Art. 1 para. 1 lit. 1 United Nations Convention on the Law of the Sea.

${ }^{45}$ Art. 150 et seq. United Nations Convention on the Law of the Sea.

${ }^{46}$ European Commission (fn 9).

${ }^{47}$ WOR 3 (fn 38), p. 102 et seq.
} 
exploitation are successfully contained. Initial research projects are going on especially in East Asian countries with limited fossil energy resources. ${ }^{48}$ After having carried out successful production tests, Japan aims at starting commercial activities in 2018 . $^{49}$

\subsubsection{One other possibility to use the seas is the desalination of salt water to provide fresh water for human consumption and irrigation}

Desalination is becoming more and more important for dry countries which primarily have to rely on rainfall. More than 780 million people around the world still lack access to clean water (United Nations 2012). Climate change may further exacerbate the situation and lead to increasing demands. One of the problems is the relatively high energy demand needed for the desalination process, but maybe solar and wind power energy will solve some problems. In any case, the use of desalination is steadily growing. According to the International Desalination Association, more than 17,000 desalination plants operate worldwide in 150 countries, producing more than 80 million cubic meters per day, providing water for 300 million people. ${ }^{50}$

Taking all in all, it becomes evident that the blue economy is steadily growing. This creates new opportunities. So, it seems justified to label this development with the term "Blue Growth." However, there is no such thing as a free lunch. Blue economy implies massive threats to the marine environment. Without going into any details, some key aspects may be summed up.

\section{Environmental impacts}

\subsection{Maritime shipping}

Maritime shipping is not the greatest environmental villain, in particular compared to the much greater impacts of land-based pollution. ${ }^{51}$ Shipping is an environmental friendly way of transportation. However, it cannot be neglected that the marine environment is endangered by the risk of accidents, as well as by discharges of operational residues and wastes, the introduction of alien species in ballast water, and the use of anti-fouling paints; emissions from ships stemming from the poor quality of heavy fuels cause air pollution, and the output of carbon dioxides contributes to climate change.

\subsection{Fisheries and aquaculture}

Overfishing and harmful fishing practices lead to detrimental impacts on the fragile marine environment, including the disturbance of habitats and biodiversity. According to FAO, almost $90 \%$ of the oceans are considered fully

\footnotetext{
$\overline{48}$ WOR 3 (fn38), p. 107; WBGU (fn 14), p. 196 et seq.

49 SPIEGELONLINE 5 March 2013, http:/www.spiegel.de/wissenschaft/technik/test-japan-foerdertmethanhydrat-aus-der-tiefsee-a-888348.html (last visit 12 February 2015).

${ }^{50} \mathrm{See}$ http://idadesal.org/desalination-101/desalination-by-the-numbers/ (last visit 12 February 2015).

${ }^{51}$ Land-based sources account for approximately $80 \%$ of marine pollution globally, cf. http://www.unesco. $\mathrm{org} / \mathrm{new} / \mathrm{en} /$ natural-sciences/ioc-oceans/priority-areas/rio-20-ocean/blueprint-for-the-future-we-want/marinepollution/facts-and-figures-on-marine-pollution/ (last visit 12 February 2015).
} 
exploited or overfished ${ }^{52}$. A number of fish stocks-for example cod-are outside safe biological limits ${ }^{53}$. This does not only affect fisheries commercially but it also has dramatic impacts on the marine ecosystem as a whole. ${ }^{54}$

That is also valid for aquaculture. The farming of fish detrimentally affects the environment through pollution, parasites, and diseases, as well as through the escape of farmed fish or the use of wild-caught fish for farming. ${ }^{55}$

\subsection{Blue biotechnology}

Blue biotechnology poses new environmental threats, for example for the biological diversity of coral reefs and hydrothermal vents. However, it is not quite easy to find more concrete information about these threats, as not enough is known about the effects on the marine environment of removing marine organisms from natural ecosystems. ${ }^{56} \mathrm{It}$ is really amazing that, instead, you find much more about the potential contribution of biotechnology to protect the marine environment. ${ }^{57}$

\subsection{Mining}

We know only too well that the extraction of oil and gas located under the sea floor may have severe impacts on sensitive marine areas and disturb marine species. "Deep Water Horizon" should serve as a serious warning. The more extraction activities are expanded to greater water depths and to remote areas, the more the hazards for the marine environment are escalating. ${ }^{58}$

Even more concerns are expressed with regard to deep sea mining. ${ }^{59}$ The exploration for, and the exploitation of, minerals from deep sea deposits will increase the human footprint on largely untouched, still unknown, and vulnerable ecosystems. Dredging for nodules is likely to affect large areas of the seabed and disperse large clouds of sediment. ${ }^{60}$ Polymetallic sulfide mining may destroy active and inactive hydrothermal vents (black smokers) and their associated communities and disperse toxic materials. ${ }^{61}$ The extraction of cobalt rich crusts may damage the benthic seamount communities and dependent fauna. ${ }^{62}$

The possible impacts of gas hydrates mining are discussed quite controversially. Scientists argue that the extraction can lead to decreasing the stability of the seabed, causing submarine landslide, and to methane leakages from the seafloor. It is also discussed whether the dissociation of gas hydrates may accelerate global warming. ${ }^{63}$

\footnotetext{
${ }^{52}$ See Food and Agricultural Organization (fn 12), p. 11, 42.

53 Ibid., p. 39; WOR 1 (fn 23), p. 124.

${ }^{54} \mathrm{Cf}$. WBGU (fn. 14), p. 115 et seq.

${ }^{55}$ For details see WOR 2 (fn 15), p. 86 et seq.; WBGU (fn. 14), p. 159 et seq.

${ }^{56}$ Cf. WBGU (fn 14), p. 54.

${ }^{57}$ Cf. European Science Foundation, p. 53.

${ }^{58}$ For details see WBGU (fn 14), p. 197.

${ }^{59}$ Cf. WBGU (fn 14), p. 51 et seq.

${ }^{60}$ See WOR 3 (fn 38), p. 73.

${ }^{61}$ Ibid., p. 92.

${ }^{62}$ Ibid., p. 80 et seq.

${ }^{63}$ See for details Carlo Giavarini, Keith Hester, Gas Hydrates: Immense Energy Potential and Environmental Challenges, p. 166 et seq.; WOR 3 (fn 41), p. 112 et seq.; Zhen-guo Zhang et al., Marine Gas Hydrates: Future Energy or Environment Killer?, Energy Procedia 16 (2012), p. 935 et seq.
} 


\subsection{Blue energy}

Even offshore wind energy - one of the cornerstones for shifting from fossil to renewable energy - cannot be generated without considering impacts on the marine environment, such as collisions, underwater noise, and bird migration. Roughly the same applies to ocean energy. Marine energy plants may affect marine mammals, fish, and seabirds. ${ }^{64}$

\subsection{Blue tourism}

As the European Commission highlights blue tourism, potential negative impacts on the marine environment must not be concealed. They range from pollution, habitat destruction, and disturbance of marine animals to considerable emissions from cruise vessels, not to mention the far greater impacts of tourist infrastructure on the coastal area. $^{65}$

\subsection{Desalination}

And even desalination processes are not without environmental problems. Water intake may cause adverse environmental impacts, as large numbers of fish and shellfish or their eggs are pulled into an industrial system, where the organisms may be killed or injured by heat, physical stress, or chemicals. And depending on the desalination methods, the brine which is returned to the sea may contain hazardous residues. ${ }^{66}$

\section{Sustainable blue growth}

Without going into many details, it is obvious that blue growth is associated with environmental threats which cannot be ignored. For taking this into account, an additional magic word is added as a precondition: sustainable. Consequently, blue growth is defined as "sustainable growth in the marine and maritime sectors." 67 Whatever that means! It is not even sure whether this term shall indicate the inclusion of the three main components of sustainable development, namely ecology, economy, and social security, intrinsically tied together, or whether it is to be understood much more generally, namely that blue growth shall be maintained at a certain level or rate. ${ }^{68}$ In any case, blue growth can only be accepted if the principles of sustainable development are applied. That requires balancing the economic and sociopolitical needs and

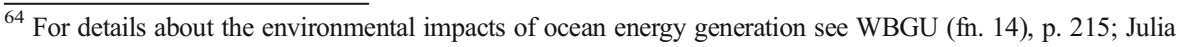
Köller et al. (ed.), Offshore Wind Energy: Research on Environmental Impacts, 2006; Lena Bergström et al., Effects of offshore windfarms on marine wildlife - a generalized impact assessment, Environ. Res. Lett. 9 (2014) 034012. Brian Polagye et al. (ed.), Environmental effects of tidal energy development, NOAA Tech. Memo. F/SPO-116; Andrea Copping et al., Environmental Effects of Marine Energy Development around the World for the OES Annex IV, 2013, www.ocean-energy-systems.org (last visit 18 March 2015).

${ }^{65}$ See John Swarbrooke, Sustainable Tourism Management, 1999, p. 155 et seq.; cf. ECORYS, p. 94.

${ }^{66}$ For details see Heather Cooley et al., Key Issues in Seawater Desalination in California - Marine impacts, 2013.

${ }^{67}$ See European Commission (fn 9), p. 2.

68 These two different definitions are mentioned e.g. by the New Oxford Dictionary.
} 
the capacities of the natural systems to meet the needs and aspirations of the present generation without compromising the ability of future generations to meet their own needs. ${ }^{69}$

So, the question is: Does blue growth open new opportunities or does it only cause nightmares? That depends on whether or not we strike the right balance. We have to find solutions which meet the needs and interests of economy including the security of existing and the creation of new jobs on the one hand and which - on the other handare environmentally friendly or at least compatible. That is my understanding of sustainable blue growth.

\section{Regulatory framework}

How to develop such a solution? I want to offer a few thoughts about some main elements and aspects which have to be taken into consideration. The first aspect to be considered is the need for an appropriate regulatory framework. The basic framework is provided by UNCLOS. ${ }^{70}$ This constitution of the sea aims at establishing a legal order which, quoting the Preamble, "will promote the peaceful uses of the seas and oceans, the equitable and efficient utilization of their resources, the conservation of their living resources, and the study, protection and preservation of the marine environment." In pursuit of this objective, UNCLOS constitutes or confirms sovereign rights of States but also creates obligations of States. The rights of States are laid down in particular in Art. 2, 56, 58, 77, and 88; they are dependent on the different maritime zones. One very fundamental obligation is created by Art. 192: "States have the obligation to protect and preserve the marine environment." This is concretized in the following articles which deal-among other aspects — with the different sources of pollution. However, as UNCLOS is only an "umbrella" convention, it has to be supplemented by more specific international agreements. A broad number of agreements exists, addressing different uses of the seas and corresponding protection measures. ${ }^{71}$

But, there are still important gaps which have to be closed. ${ }^{72}$ As far as marine biodiversity is concerned, namely the protection and preservation of rare or fragile ecosystems as well as the habitat of depleted, threatened, or endangered species and other forms of marine life, there exist still uncertainties which until now are not solved by the Convention on Biological Diversity, 1992. Deficits can also be identified with regard to the introduction of obligatory environmental principles such as sustainability and the ecosystem approach, the precautionary principle, the polluter pays principle, and the need for environment impact assessments. ${ }^{73}$

\footnotetext{
${ }^{69}$ More than 100 hundred definitions exist; this definition is derived from the definition presented by the World Commission on Environment and Development - Our Coming Future, 1987, p. 43.

${ }^{70}$ United Nations Convention on the Law of the Sea.

${ }^{71}$ For details cf. R. R. Churchill/ A. V. Lowe, The law of the sea, 3rd edition, 1999, p. 332 et seq.; WBGU (fn. 14), p. 84 .

72 The need of reform is highlighted by WBGU (fn 14), p. 106 et seq, 244 et seq.

${ }^{73}$ Part of these principles are already covered by regional marine environment conventions, such as the Convention on the Protection of the Marine Environment of the Baltic Sea Area, 1992, and the Convention for the Protection of the Marine Environment of the North-East Atlantic.
} 


\section{Ocean governance}

The establishment of regulations alone is not sufficient. What is still needed is ensuring compliance with these regulations. That requires their effective implementation and enforcement. Looking from a global perspective, there is considerable room for improvement. We need a much closer cooperation of States concerning compliance activities. This leads to the more generic question: How to manage and how to govern ocean affairs to achieve the objectives expressed in UNCLOS? Ocean governance is one of the great challenging issues, as the seas are not "owned" by individual States, but they are some kind of common goods that may be used by all, subject to the restrictions set by UNCLOS. Who is responsible for ocean governance? Are those the individual States in exercising their sovereign rights within their jurisdiction and their rights concerning the freedom of the seas? Is it sufficient that States at best cooperate in a constructive manner in intergovernmental organizations such as IMO? ${ }^{74}$ And is it sufficient that they conclude international agreements leaving the implementation and enforcement to the States? Or do we have to find some new approaches by giving more competencies to international organizations? The International Seabed Authority established under UNCLOS, being responsible for deep sea mining in the so-called Area which is understood as a common heritage of mankind, and entrusted with supranational powers, could serve as an example. And what about the participation of civil society of nongovernmental stakeholders? Do they have to be incorporated in the governance system in one way or the other? Ocean governance also is one of the magic words of our time. A Google search for "ocean governance" returns 5.5 million results. I would go beyond the scope of these considerations if I tried to cover the whole spectrum of views of what to be understood by and needed for ocean governance. Therefore, I limit myself to addressing a recent report by the WBGU, the German Advisory Council on Global Change, ${ }^{75}$ on "World in Transition-Governing the Marine Heritage" which was published in 2013. ${ }^{76}$

\section{Recommendations by the WBGU}

The considerations of the WBGU are based on three guiding principles for managing the seas in a sustainable way: ${ }^{77}$

- The oceans as a common heritage of mankind: The conservation and use of the oceans as a global public and common good $^{78}$ requires a management of sustainable stewardship.

\footnotetext{
$\overline{{ }_{74}}$ An overview about the existing relevant international institutions is given by WBGU (fn 14), p. 74 et seq.

${ }^{75}$ The WBGU is an independent scientific advisory body set up by the German Federal Government 1992 in the run-up to the Rio Earth Summit; its main task is to analyze global environment and development problems and elaborate recommendations for action and research; for details see www.wbgu.de.

${ }^{76} \mathrm{Cf}$ fn 14.

${ }^{77}$ WBGU (fn14), p. 248 et seq.

${ }^{78}$ Ibid., p. 57, 66, 248 et seq.
} 
- The systemic approach: Instead of the present sectoral approach, a systemic approach should integrate both the different levels of the system and the interactions between the natural and social systems. ${ }^{79}$

- The precautionary principle: Steps based on the state of the art in science and technology are taken to prevent possible environmental damage, even when there is no full scientific certainty on how likely it is that there actually will be any damage or how much it might cost. ${ }^{80}$

On the basis of these principles, the WBGU has elaborated a long-term vision and, knowing that such a fundamental initiative currently has little chance of implementation makes recommendations for action which link up with ongoing political processes and thus are easier to implement. ${ }^{81}$

\subsection{Long-term vision}

As a long-term vision, the WBGU recommends to extend the common heritage of mankind principle to cover all uses of all marine biological and mineral resources, but varying in specificity across the maritime zones seaward of the territorial sea. A World Oceans Organization should be set up as a global steward of the common heritage of mankind. According to the subsidiarity principle, the sustainable management of the sea as a common good should as far as possible be decentralized and left to regional and national institutions. On the high seas, newly established Regional Marine Management Organizations should shape ocean conservation and use. The coastal states should act as stewards for the marine zones entrusted to them and therefore should be accountable to the international community as regards the sustainability of the management of these zones. To strengthen its jurisdiction disputes over the law of the sea and international environmental law, and actions to prosecute cases of marine pollution should at first be assigned to the International Tribunal for the Law of the Sea. ${ }^{82}$

\subsection{WBGU recommendations for action}

At least for the time being, this vision reveals wishful thinking but is far from any chance of becoming a reality. And it only addresses the overarching legal order and principles of an organizational structure for ocean governance. However, in the end, it is the substance of regulations and standards as well as their implementation that are most important. The more it is meritorious that the WBGU also makes concrete recommendations of action as first steps for realizing a sustainable form of ocean governance. Most of them can already been taken into account under the existing legal order and therefore can be of great practical value when striving for balancing the use and the protection of the sea. Without going into any details, the most essential

\footnotetext{
${ }^{79}$ For details see ibid., p. 56, 65, 249.

${ }^{80}$ Ibid., p. 57, 66, 250.

${ }^{81}$ Ibid., p. 3, 252.

${ }^{82}$ Ibid., p. 4, 8 et seq, 252 et seq.
} 
recommendations should be briefly quoted. Even if some of them may be arguable, in any case, they are worth to be considered thoroughly.

\subsubsection{Create the necessary conditions for sustainable, long-term management}

Instead of focusing on short-term profit, a suitable institutional and political framework is needed to move toward long-term and sustainable business models. The prices for ecosystem services should be taken into consideration, harmful subsidies should be cut back, funding should be provided for sustainable capacity building. ${ }^{83}$

\subsubsection{Develop strategies for sustainable ocean governance}

An "Integrated World Oceans Strategy" should be developed including a list of sustainable development goals and passed by the UN General Assembly. The strategy should be taken up and implemented at regional, national, and local levels. ${ }^{84}$

\subsubsection{Support an implementing agreement on biological diversity on the high seas}

To close existing regulatory gaps on the high seas, issues to be regulated are the use of marine genetic resources, marine-protected areas, environmental impact assessments, and also the provision for a funding mechanism. ${ }^{85}$

\subsubsection{Advance the FSA ${ }^{86}$ and RFMOs ${ }^{87}$}

In the longer term, the FSA should be extended by adding the common heritage of mankind principle. Its jurisdiction should be expanded to cover all species fished on the high seas. Urgent action is required to encourage the RFMOs to manage their fish stocks in a sustainable manner. There should be a globally accessible register for all fishing vessels that want to operate on the high seas in RFMO areas and compulsory licensing to make illegal, unreported, and unregulated fishing more difficult. It should be made difficult or impossible for ships based in noncooperating states to use RFMO stocks. $^{88}$

\subsubsection{Strengthen and extend regional ocean governance}

In the context of the UNEP Regional Seas Programme, the development of regional agreements for all marine regions should be encouraged. ${ }^{89}$

\footnotetext{
${ }^{83}$ Ibid., p. 10, 260 et seq.

${ }^{84}$ Ibid., p. 10, 261 et seq.; as a valuable basis could serve the Ocean Compact Initiative launched by the UN Secretary General in 2012 .

${ }^{85}$ Ibid. p. 10, 263.

${ }^{86}$ Agreement for the Implementation of the Provisions of the United Nations Convention on the Law of the Sea of 12 December 1982 relating to the Conservation and Management of Straddling Fish Stocks and Highly Migratory Fish Stocks.

${ }^{87}$ Regional Fisheries Management Organizations; about the role and significances of RFMOs see WBGU (fn 14), p. 139 et seq.

${ }^{88}$ Ibid., p. 10 et seq., 264 et seq.

${ }^{89}$ Ibid., p. 11, 265 et seq..
} 


\subsubsection{Improve dovetailing in regional ocean governance}

Cooperation should be deepened between adjacent marine conservation agreements and, in the case of fisheries, between adjacent RFMOs. ${ }^{90}$

\subsubsection{Boost international financing for conservation and the sustainable use of the seas}

Following the equality principle, all states should take part in financing marine conservation. Two international funds should be set up to support measures within the EEZ and to finance the conservation of the high seas. ${ }^{91}$

\subsubsection{Strengthen and expand private governance}

Private certification initiatives aiming to encourage the sustainable use of the oceans (e.g., Marine Stewardship Council, Friend of the Sea, Aquaculture Stewardship Council) should be promoted. ${ }^{92}$

\subsubsection{Considerably expand marine-protected areas}

At least $20-30 \%$ of the area of marine ecosystems should be included in an ecologically representative and effectively managed system of protected areas. ${ }^{93}$

\subsubsection{Set up marine spatial planning}

A multilateral system of marine spatial planning that ensures cross-national coordination in order to realize large-scale environmentally friendly uses across zones should be established. ${ }^{94}$

\subsubsection{Set up a stricter liability regime}

A much more effective international liability regime should be created covering all activities across all sectors involving a potential risk to the seas. ${ }^{95}$

\section{Marine knowledge}

When striving for sustainable ocean governance, one additional aspect has to be added which is of great concern and is also stressed by the WBGU: An indispensable prerequisite is knowledge. Consequently, the WBGU recommends to strengthen the knowledge and action base of ocean governance and requires the rapid enhancement of an ocean environmental monitoring system. ${ }^{96}$ Sufficient marine knowledge is needed

\footnotetext{
${ }^{90}$ Ibid., p. 11, 268.

${ }^{91}$ Ibid., p. 11, 269 et seq.

92 Ibid., p. 11, 272 et seq.

93 Ibid., p. 11, 273 et seq.

94 Ibid., p. 12., 275.

95 Ibid., p. 12, 275.

${ }^{96}$ WBGU (fn 14), p. 10, 259 et seq. 
for the benefit of policy and decision makers to meet their responsibilities and that includes governments, public authorities, and their scientific advisors. But, it is also needed for industry interested and involved in blue growth activities. And we should never forget that conveying adequate knowledge is the key condition for creating social acceptance. On the European level, this need for knowledge has been reflected by the European Commission in a Green Paper on Marine Knowledge 2020 (European Commission and COM 2012) and the accompanying roadmap (European Commission and SWD 2014) which was released some months ago.

We have to admit that we are still at the beginning of gaining really sufficient knowledge about the oceans and the seas, about their role in the Earth system, and the impacts of human activities. Therefore, comprehensive marine research activities are urgently needed. At lot of initiatives are on their way on the European level, such as the overarching Framework Programme for Research and Innovation Horizon 2020 ${ }^{97}$ and the Joint Programming Initiative "Healthy and Productive Seas and Oceans." 98 However, research programs and projects are time-limited and focusing on specific issues. In addition, long-term ocean observations and services are needed. A global ocean observing system which in principle has been developed by the Intergovernmental Oceanographic Commission and the World Meteorological Organization, called GOOS, is indispensable. But, the implementation of this system is really difficult. One of the main obstacles is that there does not exist a clear obligatory commitment of States to contribute to such a system. ${ }^{99}$ On the European level, a marine service shall be established within the Copernicus program. ${ }^{100}$ But again, this does not include any long-term commitments for the European Member States. As concerns the marine environment monitoring, obligations are created by the EU Marine Strategy Framework Directive. ${ }^{101}$ But, as they cover only some specific aspects, they are fragmentary.

\section{Capacity building}

Sustainable ocean governance urgently requires that the decision makers are able to meet their responsibilities. Therefore, they must be provided with a sound understanding of ocean governance and management matters. This is an issue which has to be taken all the more into account with regard to education and training, in particular as far as technical cooperation and capacity building is concerned. A promising step has just recently been made by the $\mathrm{WMU}^{102}$ bearing in mind its objectives ${ }^{103}$ to be the international postgraduate education and research institution for capacity building in various aspects of shipping and related fields concerning the improvement of maritime safety and security, the protection of the marine environment, and the efficiency of

\footnotetext{
${ }^{97}$ For details see http://ec.europa.eu/programmes/horizon2020 (last visit 1 April 2015).

${ }^{98}$ For details see http://www.jpi-oceans.eu/jpi-oceans-strategy (last visit 1 April 2015).

99 See Peter Ehlers, The Governance of the Global Ozean Observing System (GOOS), in Hestermeyer et al. (ed.): Coexistence, Cooperation and Solidarity - Liber Amicorum Rüdiger Wolfrum, 2012.

${ }^{100}$ For details see http://www.copernicus.eu (last visit 7 May 2015).

${ }^{101}$ Directive 2008/56/EC of the European Parliament and of the Council of 17 June 2008 (OJ L 164, 25.6.2008, p. 19).

102 World Maritime University

${ }^{103}$ See Art. 2 para a Charter of the World Maritime University, IMO Resolution A 1030(26).
} 
international shipping, in furtherance of the purposes and objectives of IMO. ${ }^{104}$ WMU has just decided to expand its scope to include ocean-related matters. ${ }^{105}$ On this issue, a specialization on ocean governance and management will be designed covering topics such as seafarers rights, fisheries, ocean health and sustainability, ocean energy, deep-sea resource development, marine science, marine spatial planning, environmental impact assessments, ocean law, and policy. As these matters go beyond the objectives of IMO, a close cooperation not only with other ocean-related international bodies, especially in the UN system, is required but also with nongovernmental organizations representing ocean industry and marine environment protection interests. The expansion of WMU's topics does not only affect the teaching of respective policy matters but also require the support by concomitant research projects in the wider field of ocean and marine policies. For this purpose, it is intended to establish a Maritime and Ocean Policy Research Institute within WMU. ${ }^{106}$ In this context, the Chairman of the Nippon Foundation made a very encouraging announcement on the occasion of the inauguration of the new WMU building in Malmö, Sweden. The foundation is prepared to set up a special endowment fund worth 100 million USD. This Nippon Foundation-WMU Ocean Fund will "support WMU to establish itself as first, an ocean and maritime research institution which engages in multidisciplinary scientific research in the marine field; and second, an educational institution that generates human resources who have the capacity to address ocean issues with a multidisciplinary approach. ${ }^{107}$ In the light of this development, it may be expected that in future, WMU will contribute to a high degree to the education of future leaders in maritime and ocean fields all over the world and in particular for developing countries.

\section{Conclusions}

What are the conclusions? For finding a sound balance between the use and the protection of the seas, a sustainable and comprehensive ocean governance system is urgently needed. The seas will continue gaining in importance as part of a healthy economy. They satisfy elemental needs, e.g., for food, natural resources, and energy supply, and as transport routes, they are a fundamental basis for the worldwide exchange of goods. The increasing use that is made of the seas requires a very careful weighing of the different user interests against one another, but in particular against environmental concerns; this is of vital importance to achieve a sustainable development and to ensure that an equilibrium is maintained.

\footnotetext{
$\overline{104}$ International Maritime Organization

105 See for details Study of the Financial Sustainability of the World Maritime University, Section 3, Strategy 3 and 4; cf. IMO A 29/18(a), p. 7.

106 Ibid., Section 4, para 4.4.

107 Address by Yohei Sasakawa, Chairman of the Nippon Foundation, on 19 May 2015.
} 
In summary, the following points are of paramount importance for improving ocean governance:

- Marine knowledge has to be increased significantly by intensifying marine research activities and creating binding commitments for long-term ocean observations and services.

- International cooperation has to be enhanced and should be guided by an integrated world oceans strategy initiated by the UN and based on the principles highlighted by WBGU (common heritage, systemic approach and precautionary principle) as a joint basis for a close cooperation of all ocean-related international bodies which in the long run may lead to a World Oceans Organization, supplemented by Regional Marine Management Organizations.

- An international system for financing the conservation and sustainable use of the seas has to be established, taking into account an internalization of the costs for preserving marine ecosystems.

- The law of the sea has to be further developed to fill still existing gaps in particular with regard to marine biological diversity including the designation of marineprotected areas, the extension of the FSA, and the introduction of large-scale marine spatial planning.

- Activities for capacity building have to be intensified for strengthening the focus on ocean policy and management, among others by supporting and promoting WMU's firm intention to expand its scope to include ocean-related matters.

We should be very conscious that the seas are indispensable for human life and survival. That is impressively illustrated by a quotation attributed to the science fiction author Arthur C. Clarke:

"How inappropriate to call this planet Earth when it is quite clearly Ocean".

\section{References}

ECORYS (2013) Study in support of policy measures for coastal and maritime tourism at EU level 21

European Commission, COM (2012) 473

European Commission, SWD (2014) 149 final

European Science Foundation (2010) Marine biotechnology: a new vision and strategy for Europe, Position Paper 15: 9

Milton J (1674), Paradise Lost, Book 2, lines 891-894. Graf Vitzthum, Handbuch des Seerechts, 2006, Chapt. 2 , n. 1, who coined this term

United Nations (2012) The millennium development goals report 52 